Article

\title{
Serum 25(OH) Vitamin D Levels in Polish Women during Pregnancies Complicated by Hypertensive Disorders and Gestational Diabetes
}

\author{
Piotr Domaracki ${ }^{1}$, Pawel Sadlecki ${ }^{1}$, Grazyna Odrowaz-Sypniewska ${ }^{2}$, Ewa Dzikowska ${ }^{1}$, \\ Pawel Walentowicz ${ }^{1}$, Joanna Siodmiak ${ }^{2}$, Marek Grabiec ${ }^{1}$ and \\ Malgorzata Walentowicz-Sadlecka ${ }^{1, *}$ \\ 1 Department of Obstetrics and Gynecology, L. Rydygier Collegium in Bydgoszcz, \\ Nicolaus Copernicus University, ul. Ujejskiego 75, Bydgoszcz 85-168, Poland; \\ domarackipiotr@gmail.com (P.D.); pawelsadlecki@wp.pl (P.S.); evi1710@op.pl (E.D.); \\ walentowiczp@gmail.com (P.W.); grabiecm@cm.umk.pl (M.G.) \\ 2 Department of Laboratory Medicine, L. Rydygier Collegium in Bydgoszcz, \\ Nicolaus Copernicus University, M. Curie Skłodowskiej 9, Bydgoszcz 85-094, Poland; \\ grazynaodes@interia.pl (G.O.-S.); asiapollak@wp.pl (J.S.) \\ * Correspondence: walentowiczm@cm.umk.pl; Tel.: +48-60-7636467; Fax: +48-52-3655245 \\ Academic Editors: Maurizio Battino and Charles Brennan \\ Received: 29 June 2016; Accepted: 9 September 2016; Published: 27 September 2016
}

\begin{abstract}
Background: An association between the level of vitamin D and the risk of pregnancy-related complications remains unclear. The aim of this study was to examine concentrations of 25(OH) vitamin D in Polish women with normal pregnancies and pregnancies complicated by gestational hypertension, preeclampsia or gestational diabetes mellitus (GDM). Moreover, we analyzed an association between maternal serum $25(\mathrm{OH}) \mathrm{D}$ and the risk of gestational hypertension, preeclampsia and GDM. Material and Methods: The study included 207 pregnant women, among them 171 with pregnancy-related complications: gestational hypertension $(n=45)$, preeclampsia $(n=23)$ or GDM $(n=103)$. The control group consisted of 36 women with normal pregnancies. Concentrations of serum $25(\mathrm{OH}) \mathrm{D}$ were measured at admission to the hospital prior to delivery Results: Patients with hypertension did not differ significantly from the controls in terms of their serum $25(\mathrm{OH}) \mathrm{D}$ concentrations $(18.20 \mathrm{vs} .22 .10 \mathrm{ng} / \mathrm{mL}, p=0.15)$. Highly significant differences were found in $25(\mathrm{OH}) \mathrm{D}$ concentrations of women with preeclampsia and the controls ( 14.75 vs. $22.10 \mathrm{ng} / \mathrm{mL}, p=0.0021)$. GDM was not associated with significant differences in $25(\mathrm{OH}) \mathrm{D}$ concentration. A low level of $25(\mathrm{OH}) \mathrm{D}$ turned out to be associated with an increased risk of preeclampsia during pregnancy on both univariate and multivariate regression analysis, and was a significant predictor of this condition on ROC (receiver operating characteristic) analysis (AUC $=0.70, p<0.01)$. Conclusions: $25(\mathrm{OH}) \mathrm{D}$ deficiency is common among pregnant Polish women. Low concentrations of $25(\mathrm{OH}) \mathrm{D}$ may play a role in the etiopathogenesis of preeclampsia. Routine assessment of the $25(\mathrm{OH}) \mathrm{D}$ level during pregnancy may be crucial for the identification of women at increased risk of preeclampsia.
\end{abstract}

Keywords: 25(OH)D; gestational hypertension; preeclampsia; gestational diabetes

\section{Introduction}

Vitamin 25(OH)D insufficiency/deficiency is currently recognized as a pandemic. Vitamin D insufficiency and deficiency occur in $9.3 \%-41.4 \%$ and $22.7 \%-90.3 \%$ of pregnant women, respectively [1]. Vitamin $25(\mathrm{OH}) \mathrm{D}$ deficiency results primarily from unawareness that moderate sun exposure constitutes the principal source of vitamin D3 in most humans [2]. The active form of vitamin D, i.e., 
$1,25(\mathrm{OH})_{2} \mathrm{D}$, is now recognized as an important hormone playing a crucial role in skeletal homeostasis (classical effects) and exerting non-classical effects in various pathological and physiological conditions, such as cancer, arterial hypertension, cardiovascular diseases, brain development and immunomodulation [3-6].

Vitamin D3 is transported to the liver from the skin and intestines by vitamin D-binding protein (DBP) [7]. Here, it is hydroxylated to $25(\mathrm{OH}) \mathrm{D}$, a major form of vitamin $\mathrm{D}$ found in the blood. Blood concentration of 25(OH)D reflects actual content of vitamin D in the human body [7]. The most active form of vitamin D, 1,25-dihydroxy-vitamin D, is synthesized in kidneys, as well as in other tissues and cells, e.g., parathyroid glands, prostate, macrophages, immune and reproductive cells [8]. The fact that $25(\mathrm{OH}) \mathrm{D}$ passes through the placenta to the fetus in early pregnancy, points to a pivotal role of appropriate dietary intake of vitamin D in pregnant women [9]. According to the Endocrine Society, insufficiency and deficiency of vitamin D are defined as concentrations of $25(\mathrm{OH}) \mathrm{D}$ equal to $20-30 \mathrm{ng} / \mathrm{mL}$ and $<20 \mathrm{ng} / \mathrm{mL}$, respectively. In turn, serum concentrations of $25(\mathrm{OH}) \mathrm{D}$ above $30 \mathrm{ng} / \mathrm{mL}$ are considered normal [9]. Deficiency of vitamin D is commonly diagnosed among pregnant women worldwide, and was shown to be associated with an increased risk of pregnancy-related complications [1].

Hypertensive disorders and gestational diabetes mellitus (GDM) are principal causes of morbidity and mortality in pregnant women, their fetuses and newborns [10,11]. Every tenth pregnant woman is diagnosed with gestational hypertension $(\mathrm{GH})$, one of the most common complications and a leading cause of maternal mortality worldwide $[12,13]$. GH is the second most common cause of perinatal mortality due to hemorrhage in pregnant Polish women [14]. Depending on the study population and diagnostic criteria, prevalence of $\mathrm{GH}$ is estimated at $2 \%-7 \%$. The risk of this complication was shown to increase with age, nulliparity, history of preeclampsia (PE) in previous pregnancies, diabetes mellitus and obesity $[10,15]$. PE is defined as hypertension $(\geq 140 / 90 \mathrm{mmHg})$ and proteinuria, starting after 20 weeks of gestation [16]. Preeclampsia occurs in 5\%-6\% of pregnancies and constitutes one of the most common causes of perinatal complications, maternal, fetal and neonatal mortality [17-19].

GDM is another common complication of pregnancy. It is defined as glucose intolerance of any degree, which started or has been newly diagnosed in pregnancy. Depending on the study population and diagnostic criteria, GDM may affect up to $18 \%$ of pregnant women [20]. Principal risk factors of GDM include older age at conception and obesity. According to literature, a growing proportion of women decide to get pregnant at an older age, and the average age of getting pregnant is still increasing [21,22]. Metabolic disorders associated with GDM may negatively affect fetal development, which typically results in macrosomia, complicated labor, and perhaps also some postnatal complications related to fetal programming [23].

Although the biological role of vitamin D has been studied extensively, the consequences of its deficiency for maternal, fetal and neonatal health are still unclear [4,22,24]. The aim of this study was to determine serum concentrations of $25(\mathrm{OH}) \mathrm{D}$ in Polish women with uncomplicated pregnancies and pregnancies complicated by hypertension, preeclampsia and diabetes mellitus. Moreover, we analyzed an association between the concentration of $25(\mathrm{OH}) \mathrm{D}$ in maternal serum and the risk of hypertension, preeclampsia and diabetes mellitus.

\section{Results}

Concentrations of $25(\mathrm{OH}) \mathrm{D}$ within the range $(\geq 30 \mathrm{ng} / \mathrm{mL})$ was observed only in $10.8 \%$ patients. Insufficient concentrations of $25(\mathrm{OH}) \mathrm{D}(20-30 \mathrm{ng} / \mathrm{mL})$ were found in $43.7 \%$ of pregnant women from the study group. However, deficiency of vitamin D (concentration $25(\mathrm{OH}) \mathrm{D}<20 \mathrm{ng} / \mathrm{mL}$ ) was recognized in as many as $45.6 \%$ patients participating in the study. The results are presented in Table 1. 
Table 1. Concentration of $25(\mathrm{OH}) \mathrm{D}(\mathrm{ng} / \mathrm{mL})$ in the study group.

\begin{tabular}{ccc}
\hline 25(OH)D Concentration $(\mathbf{n g} / \mathbf{m L})$ & Study Group $(\boldsymbol{N}=\mathbf{1 7 1})$ & Control Group $(\boldsymbol{N}=\mathbf{3 6})$ \\
\hline Sufficient concentration: $25(\mathrm{OH}) \mathrm{D} \geq 30$ & $18(10.8 \%)$ & $11(30.5 \%)$ \\
Insufficientconcentration: 25(OH)D: $20-30$ & $75(43.7 \%)$ & $15(41.7 \%)$ \\
Deficiency: $25(\mathrm{OH}) \mathrm{D}<20$ & $78(45.6 \%)$ & $10(27.8 \%)$ \\
\hline
\end{tabular}

25(OH)D concentration did not differ significantly $(p=0.08)$ between groups considering seasons of taking blood (spring/summer vs. autumn/winter, 21.1 vs. $19.5 \mathrm{ng} / \mathrm{mL}, p=\mathrm{NS}$ ). Serum levels of $25(\mathrm{OH})(\mathrm{ng} / \mathrm{mL})$ did not correlate significantly with pregnancy duration, neonatal birth weight and $\mathrm{pH}$ of the umbilical cord blood (data not shown).

$25(\mathrm{OH}) \mathrm{D}$ concentration did not differ significantly $(p=0.0623)$ between the group of patients with hypertension and the control group (18.20 vs. $22.10 \mathrm{ng} / \mathrm{mL} p=0.1481)$. However, there were high significant differences in $25(\mathrm{OH}) \mathrm{D}$ concentration between the group of women with preeclampsia and the control group (14.75 vs. $22.10 \mathrm{ng} / \mathrm{mL}, p=0.0021)$. There were no differences in $25(\mathrm{OH}) \mathrm{D}$ concentration between the group with GDM G1 $(20.80 \mathrm{ng} / \mathrm{mL})$, the group with GDM G2 $(22.60 \mathrm{ng} / \mathrm{mL})$ and the control group $(22.10 \mathrm{ng} / \mathrm{mL})(p=0.9207)$. The results are presented in Table 2.

Table 2. Serum concentrations of $25(\mathrm{OH}) \mathrm{D}(\mathrm{ng} / \mathrm{mL})$ in various subsets of patients (Q1-lower quartile; Q3 - upper quartile; SD—standard deviation; NS—non-significant; GH—gestational hypertension; PE—preeclampsia; GDM—gestational diabetes mellitus).

\begin{tabular}{|c|c|c|c|c|c|c|c|c|c|}
\hline $\begin{array}{c}25(\mathrm{OH}) \mathrm{D} \\
\mathrm{ng} / \mathrm{mL}\end{array}$ & $N$ & Mean & SD & Minimum & Q1 & Median & Q3 & Maximum & $\begin{array}{c}\text { Mann-Whitney } \\
U \text {-Text }\end{array}$ \\
\hline $\mathrm{GH}$ & 45 & 19.01 & 7.36 & 8.00 & 13.70 & 18.20 & 24.30 & 37.50 & \multirow[b]{2}{*}{ NS } \\
\hline Controls & 36 & 21.65 & 5.13 & 14.60 & 16.95 & 22.10 & 24.90 & 32.30 & \\
\hline PE & 23 & 21.65 & 5.13 & 14.60 & 16.95 & 22.10 & 24.90 & 32.30 & \multirow{2}{*}{$\begin{aligned} Z & =3.0759 \\
p & =0.0021\end{aligned}$} \\
\hline Controls & 36 & 21.65 & 5.13 & 14.60 & 16.95 & 22.10 & 24.90 & 32.30 & \\
\hline GDM & 103 & 21.99 & 7.43 & 9.40 & 15.50 & 22.10 & 27.30 & 47.10 & \multirow[b]{2}{*}{ NS } \\
\hline Controls & 36 & 21.65 & 5.13 & 14.60 & 16.95 & 22.10 & 24.90 & 32.30 & \\
\hline
\end{tabular}

ROC analyses were performed to assess the relationship between $25(\mathrm{OH}) \mathrm{D}$ and the incidence of gestational hypertension (GH), preeclampsia (PE) and gestational diabetes mellitus (GDM) (Table 3).

Table 3. Relationships between serum concentrations of $25(\mathrm{OH}) \mathrm{D}$ and the incidence of pregnancy-induced hypertension (PIH); gestational hypertension (GH); preeclampsia (PE); gestational diabetes mellitus (GDM); results of ROC (receiver operating characteristic) analysis.

\begin{tabular}{cccc}
\hline Parameter & GH & PE & GDM \\
\hline AUC & 0.5767 & 0.7029 & 0.5721 \\
SE (AUC) & 0.0509 & 0.0631 & 0.0462 \\
$-95 \%$ CI & 0.4769 & 0.5792 & 0.4817 \\
$+95 \%$ CI & 0.6765 & 0.8265 & 0.6626 \\
Z-statistic & 1.4806 & 3.0486 & 1.5096 \\
$p$ & 0.1387 & 0.0023 & 0.1311 \\
Cut-off value & 0.3541 & 8 & 9.4 \\
\hline
\end{tabular}

In ROC analysis $25(\mathrm{OH}) \mathrm{D}$ was not a significant variable of the incidence of gestational hypertension (Figure 1). 


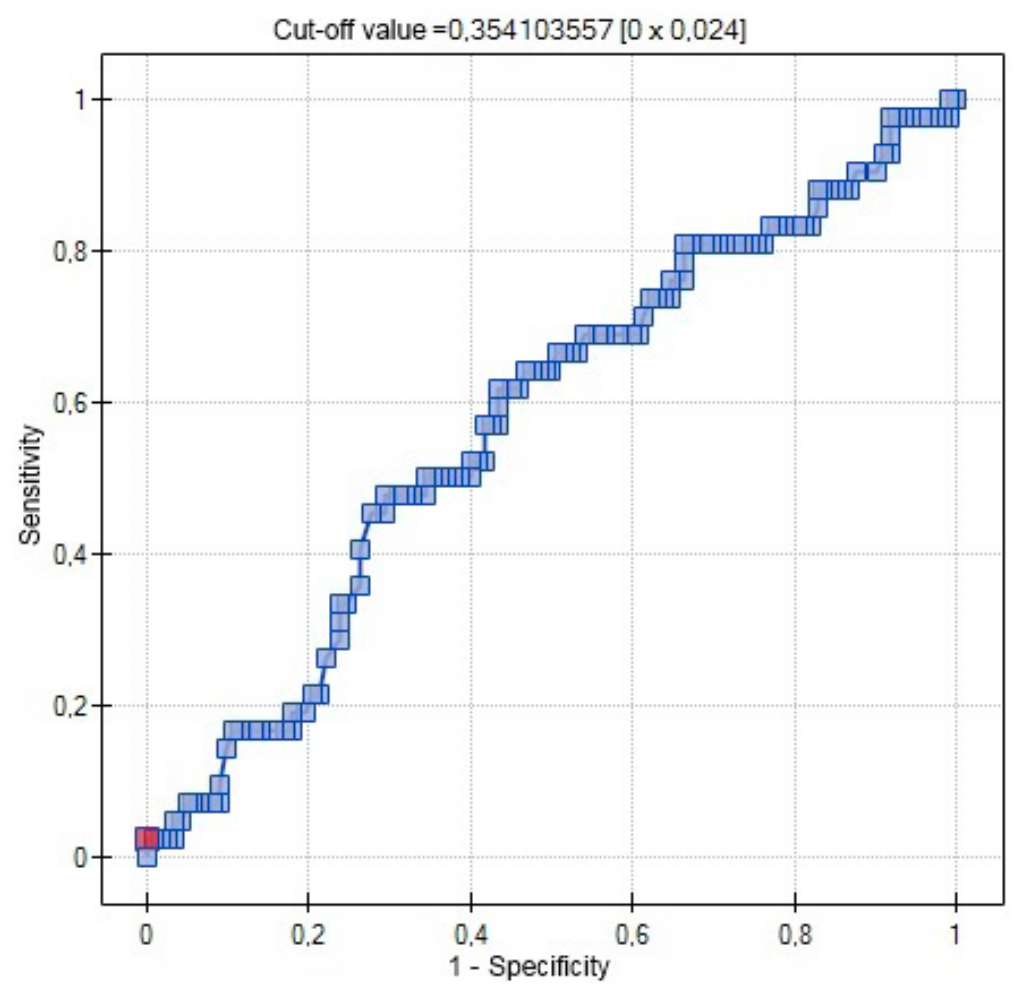

Figure 1. ROC curve relationship between $25(\mathrm{OH}) \mathrm{D}$ concentrations $(\mathrm{ng} / \mathrm{mL})$ and occurrence of gestational hypertension (red point-cut-off value).

In the ROC analysis serum 25(OH)D was a significant destimulator of the incidence of preeclampsia $(p=0.0023)$, with the area under the ROC curve (AUC) equal to $70.3 \%$. (Figure 2 ).

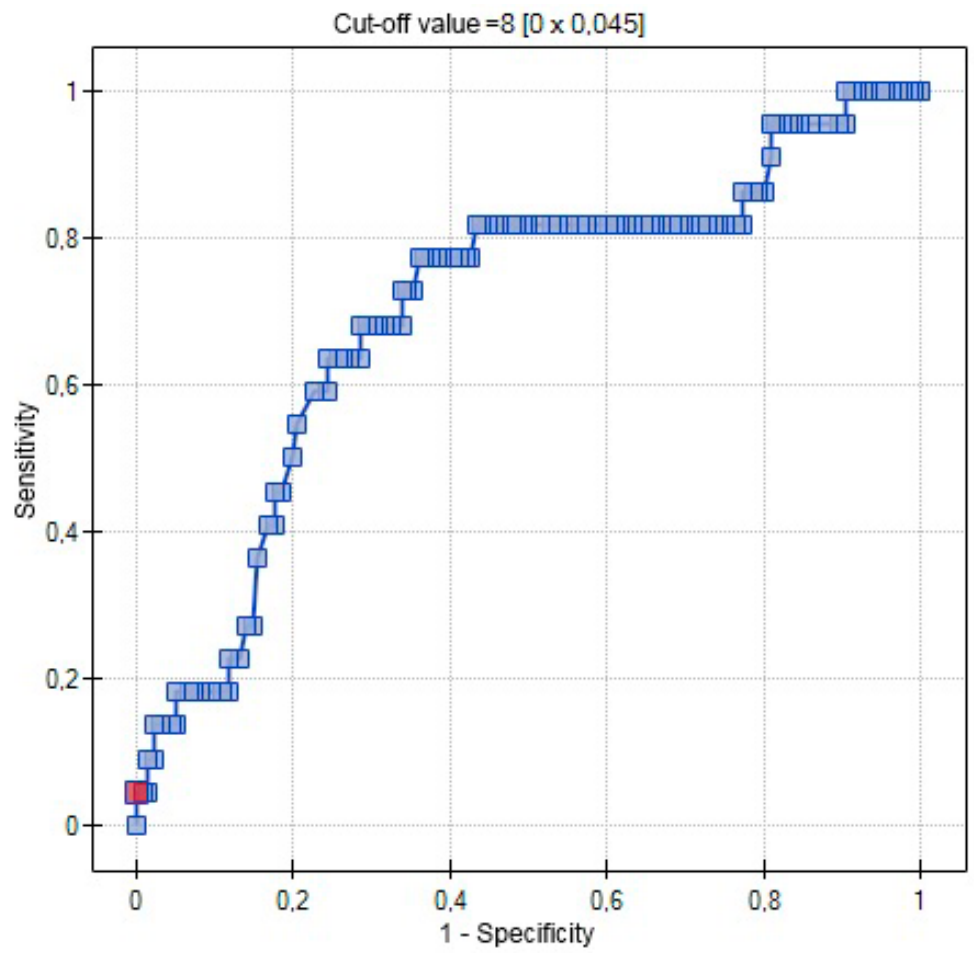

Figure 2. ROC curve-relationship between $25(\mathrm{OH}) \mathrm{D}$ concentrations $(\mathrm{ng} / \mathrm{mL})$ and occurrence of preeclampsia (AUC 0.7029), (red point-cut-off value). 
In ROC analysis $25(\mathrm{OH}) \mathrm{D}$ was not a significant variable influencing the incidence of diabetes (Figure 3).

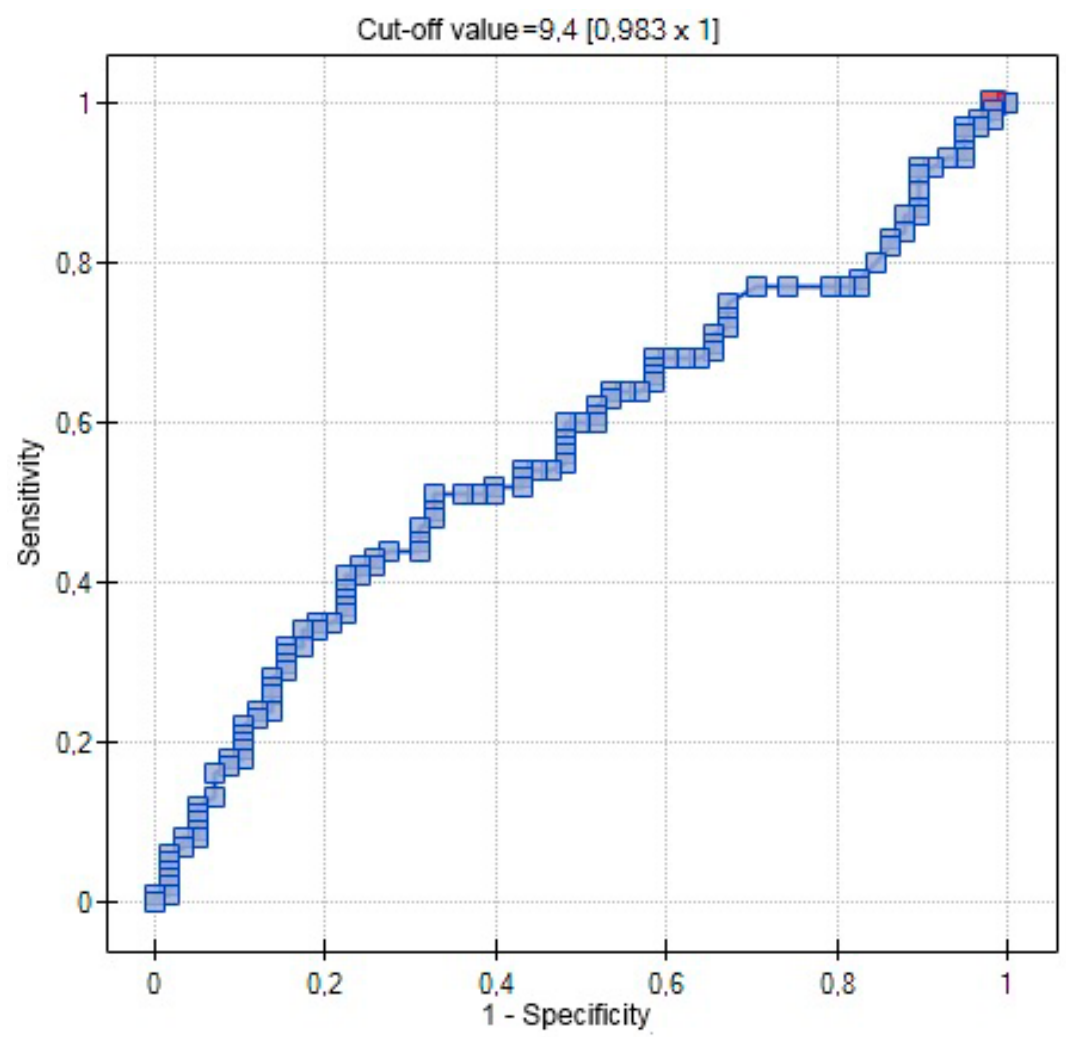

Figure 3. ROC curve-relationship between $25(\mathrm{OH}) \mathrm{D}$ concentrations $(\mathrm{ng} / \mathrm{mL})$ and occurrence of diabetes (AUC 0.5721) (red point—cut-off value).

Univariate and multivariate logistic regression analysis was conducted to verify if the effects of serum $25(\mathrm{OH}) \mathrm{D}$ levels on the incidence of preeclampsia are independent of other established risk factors (age $>35$, primiparity) of these conditions (Table 4).

Table 4. Results of univariate and multivariate logistic regression analysis examining the effects of serum $25(\mathrm{OH}) \mathrm{D}$ levels $(\mathrm{ng} / \mathrm{mL})$, age and primiparity on the incidence of preeclampsia.

\begin{tabular}{cccccc}
\hline Parameter & $\boldsymbol{b}$-Coefficient & $\boldsymbol{p}$-Value & Odd Ratio & $\mathbf{+ 9 5 \%}$ CI & $\mathbf{+ 9 5 \% ~ C I ~}$ \\
\hline Intercept & 0.4965 & 0.5113 & 1.6429 & 0.3735 & 7.2268 \\
25(OH)D $(\mathrm{ng} / \mathrm{mL})$ & -0.1208 & 0.0033 & 0.8862 & 0.8177 & 0.9605 \\
Intercept & 0.0467 & 0.9703 & 1.0478 & 0.0899 & 12.2172 \\
Age $>$ 35 years old & -0.0644 & 0.1298 & 0.9377 & 0.8627 & 1.0191 \\
Intercept & -2.6509 & $<0.0001$ & 0.0706 & 0.0308 & 0.1615 \\
Primiparity & 1.3410 & 0.0077 & 3.8228 & 1.4260 & 10.2478 \\
Intercept & 0.3649 & 0.8328 & 1.4403 & 0.0487 & 42.5836 \\
25(OH)D $(\mathrm{ng} / \mathrm{mL})$ & -0.1170 & 0.0053 & 0.8896 & 0.8195 & 0.9658 \\
Age $>$ 35 years old & -0.0267 & 0,5818 & 0.9737 & 0.8856 & 1.0706 \\
Primiparity & 1.3980 & 0.0166 & 4.0469 & 1.2893 & 12.7030 \\
\hline
\end{tabular}

Serum $25(\mathrm{OH}) \mathrm{D}(\mathrm{ng} / \mathrm{mL})$ and primiparity were identified as an independent predictor of preeclampsia on both univariate and multivariate logistic regression analyses. Low serum $25(\mathrm{OH}) \mathrm{D}$ levels and primiparity increased the risk of preeclampsia. 


\section{Discussion}

Only recently have we started to understand the developmental origins of diseases and the influence of perinatal environment on lifelong health. Despite widespread deficiency of vitamin D among pregnant women worldwide, its role in pregnancy has largely been ignored [25-27]. Only $10.8 \%$ of our patients presented sufficient serum concentrations of $25(\mathrm{OH}) \mathrm{D}(\geq 30 \mathrm{ng} / \mathrm{mL})$, and the diagnostic criteria for vitamin D insufficiency and deficiency (i.e., $25(\mathrm{OH}) \mathrm{D} 20-30 \mathrm{ng} / \mathrm{mL}$ or $<20 \mathrm{ng} / \mathrm{mL}$ ) were satisfied by $43.7 \%$ and $45.6 \%$ of the study subjects, respectively. One potential explanation for such a high prevalence of vitamin D insufficiency/deficiency among pregnant Polish women is a relatively low number of sunny days in our country. Furthermore, most pregnant women are known to avoid sun exposure. Finally, low serum concentrations of $25(\mathrm{OH}) \mathrm{D}$ observed in our series might also result from an inadequate supplementation of this vitamin. Our findings are consistent with the results of another study conducted in a central European population, which also documented a high prevalence of vitamin D deficiency [23].

Taking into account inconclusive results of cross-sectional and cohort studies analyzing the association between vitamin $\mathrm{D}$ status and occurrence of pregnancy pathologies [28,29], the aim of our study was to asses $25(\mathrm{OH}) \mathrm{D}$ status in women with gestational hypertension $(\mathrm{GH})$. Our study showed that pregnant women with GH and healthy controls did not differ significantly in terms of their 25(OH)D concentrations ( $18.20 \mathrm{ng} / \mathrm{mL}$ vs. $22.10 \mathrm{ng} / \mathrm{mL}, p=0.1481)$, and serum $25(\mathrm{OH}) \mathrm{D}$ has not been identified as a significant predictor of $\mathrm{GH}$ on either logistic regression analysis or ROC analysis. These observations are consistent with the results published by Bärebring et al. [13] who demonstrated that vitamin D status correlates significantly with blood pressure during the first trimester and gestational systolic blood pressure trajectory, but not with the prevalence of GH. The relationship between vitamin D status and GH has also been a subject of other studies. Van Weert et al. analyzed associations between vitamin $\mathrm{D}$ status, blood pressure at the onset of pregnancy and occurrence of a mid-pregnancy decrease in the latter parameters. Moreover, the authors searched for a potential mechanism explaining the association between vitamin D status and pregnancy-related hypertensive disorders. Similar to our study, they found no association between vitamin D status, prevalence of $\mathrm{GH}$, blood pressure at early gestation and mid-pregnancy decrease in this parameter [30]. Similar findings were reported by Powe et al., who did not observe a relationship between the level of $25(\mathrm{OH}) \mathrm{D}$, systolic and diastolic blood pressure. The same study did not document significant differences in $25(\mathrm{OH}) \mathrm{D}$ concentrations in women who developed hypertension later in pregnancy and those who did not [31]. In contrast, Burris et al. showed that the risk of GH increased by $33 \%$ per each additional $25 \mathrm{nmol} / \mathrm{L}$ of serum $25(\mathrm{OH}) \mathrm{D}$. Although this observation was interpreted as a random finding, women with higher $25(\mathrm{OH}) \mathrm{D}$ levels were still at increased risk of gestational hypertension [29]. Perhaps, women who already had been diagnosed with GH were more compliant with the recommended multivitamin intake, which was eventually reflected by their higher serum concentrations of 25(OH)D [29].

In our opinion, some discrepancies between the results of previous studies may result from lack of adjustment for vitamin D supplementation and season of the blood sampling. Consequently, the effect of serum $25(\mathrm{OH}) \mathrm{D}$ on the occurrence and clinical presentation of gestational hypertension still needs to be elucidated, in line with Hill's criteria [32]. Hence, we postulate to conduct a well-designed randomized study to assess the role of vitamin D in the etiopathogenesis of GH.

In this study, we found evident, statistically significant differences in serum concentrations of 25(OH)D in women with PE and healthy controls $(14.75 \mathrm{ng} / \mathrm{mL}$ vs. $22.10 \mathrm{ng} / \mathrm{mL}, p=0.0021)$. Moreover, a significant association between serum $25(\mathrm{OH}) \mathrm{D}$ and $\mathrm{PE}(p=0.0023)$ was documented on ROC analysis, with the area under the ROC curve (AUC) equal to 70.3\%. Consequently, we conducted a logistic regression analysis to verify if the effects of serum $25(\mathrm{OH}) \mathrm{D}$ on the incidence of preeclampsia are independent of other established risk factors of this condition (age $>35$ years, primiparity). Both low serum concentration of $25(\mathrm{OH}) \mathrm{D}(\mathrm{ng} / \mathrm{mL})$ and primiparity were identified as independent predictors of PE ( $p=0.0019)$ on multivariate logistic regression analysis. Our results presented here, obtained in a cohort of pregnant Polish women, are consistent with previously reported findings [32]. According to 
Barebring et al., at least a $30 \mathrm{nmol} / \mathrm{L}$ increase in serum 25(OH)D concentration is associated with lower odds of PE, regardless of vitamin D status in early pregnancy [13]. Similar to our study, these authors found an inverse association between the occurrence of PE and serum concentration of $25(\mathrm{OH}) \mathrm{D}$ during the third trimester. In our study, we determined vitamin D status at a single time point, shortly before delivery. It would be interesting to measure vitamin $\mathrm{D}$ levels throughout the whole pregnancy. Previous studies demonstrated that the level of $25(\mathrm{OH}) \mathrm{D}$ in the first trimester was not related to the risk of PE [13]. Consequently, vitamin D level in early pregnancy is less likely to play a major role in placental development, and it is later increased in this parameter which may prevent the development of PE [13]. The mechanism through which a low concentration of vitamin D contributes to preeclampsia is still unclear. $1,25(\mathrm{OH}) 2 \mathrm{D}$ was postulated to modulate immunological tolerance during pregnancy, which may explain its role in PE pathogenesis [33,34].

Another potential explanation for the association between serum $25(\mathrm{OH}) \mathrm{D}$ and occurrence of $\mathrm{PE}$ may stem from the fact that the latter condition is associated with impaired placentation and maternal endothelial dysfunction [16]. Preeclampsia in patients with vitamin D insufficiency may be linked to a low concentration of the vascular endothelial growth factor (VEGF) and high levels of inflammatory cytokines; expressions of these factors are under a strong influence of vitamin D [35-38].

Both a recent meta-analysis and several observational studies showed a significant association between vitamin D deficiency and increased risk for preeclampsia [39-41]. Similar to our study, Pena et al. demonstrated that preeclamptic women more often present a 25(OH)D deficiency shortly prior to delivery [42]. Also, Mohaghegh et al. reported significantly lower mean levels of 25(OH)D in preeclamptic women [43]. Some evidence suggests that preeclampsia may be associated with a decrease in placental and fetal concentrations of vitamin D, and placental dysfunction plays an important role in the pathogenesis of PE [44]. Appropriate development and function of the placenta are prerequisites of normal pregnancy outcome. During pregnancy, 1,25(OH)2D3 may be synthesized not only by kidneys but also by trophoblast. The human placenta and decidua are capable of producing and secreting $1,25(\mathrm{OH}) 2 \mathrm{D} 3$, and some studies analyzed mRNA expression of $1 \alpha$-hydroxylase and receptor VDR [45]. Although preeclampsia has been linked to maternal vitamin D insufficiency/deficiency, still little is known on potential differences in placental metabolism of this vitamin in uncomplicated and preeclamptic pregnancies [32].

Owing the potential contribution of an altered vitamin D metabolism to diabetes mellitus, we compared serum concentrations of 25(OH)D in patients with type 1 and 2 GDM (GDM G1 and GDM G2) and healthy controls. The analyzed groups did not differ significantly in terms of their $25(\mathrm{OH}) \mathrm{D}$ concentrations ( $20.80 \mathrm{ng} / \mathrm{mL}$ vs. $22.60 \mathrm{ng} / \mathrm{mL}$ vs. $22.10 \mathrm{ng} / \mathrm{mL}, p=0.9207)$, and 25(OH)D was not identified as a significant predictor of GDM on ROC analysis.

Our findings are consistent with the results of the study conducted by Farrant et al. [46] who also did not find a link between the concentration of $25(\mathrm{OH}) \mathrm{D}$ and prevalence of diabetes mellitus among 559 pregnant women from India [46]. Also, Loy et al. did not observe a relationship between 25(OH)D inefficiency/deficiency and GDM [47]. In the B.A.B.Y. study, an increase in serum concentration of $25(\mathrm{OH}) \mathrm{D}$ was associated with a greater risk for gestational diabetes mellitus, but only among Hispanic women [48]. Similar to our study, Pleskacova et al. did not observe significant differences in vitamin $\mathrm{D}$ levels among pregnant women and healthy controls; nevertheless, the prevalence of a vitamin D deficiency in both groups was quite high [23]. However, published evidence regarding the relationship between vitamin D level and occurrence of GDM is inconclusive. Furthermore, a direct link between glucose metabolism and vitamin D pathways has been identified. 1,25(OH)2D may induce insulin secretion and was shown to contribute to a decrease in insulin resistance; therefore, low levels of this vitamin may play a role in the development of GDM [32]. A meta-analysis conducted by Zhang et al. demonstrated that deficiency of vitamin D may predispose to GDM. Consequently, these authors recommended to conduct a well-designed randomized controlled trial to examine the exact role of vitamin D supplementation in the prevention of GDM [49]. To summarize, the link between vitamin D and glucose metabolism requires further studies on larger populations of pregnant women. 


\section{Materials and Methods}

Initially, a total of 244 patients were enrolled, but then women with multiple pregnancies $(N=5)$, intrauterine growth restriction $(N=7)$, premature rupture of membranes $(N=5)$ and hypothyroidism were excluded $(N=9)$, as well as the participants with heart problems and other co morbidities $(N=11)$. The study group was recruited from patients hospitalized at the Department of Obstetrics and Gynecology in University Hospital in Bydgoszcz. A total of 207 women, aged 19-40 years old, in singleton pregnancy, were included in the study (all Caucasian of Polish nationality, from Kuyavian-Pomeranian Region). The research was conducted in 2013-2015 at the Department of Obstetrics and Gynecology, Ludwik Rydygier Collegium Medicum in Bydgoszcz, Nicolaus Copernicus University of Torun.

A total of 45 women developed arterial hypertension during pregnancy, and 23 were diagnosed with preeclampsia. GDM was detected in 103 patients. In 84 patients GDM G2 occurred and in 19 patients GDM G1. Patients were stratified according to GDM type, G1 or G2, in line with the White classification [50]. Type A1 (corresponding to GDM G1) was defined as abnormal oral glucose tolerance test (OGTT), but normal blood glucose levels during fasting and one/two hours after a meal; diet modification was sufficient to control glucose levels. Type A2 (corresponding to GDM G2) was defined as abnormal OGTT compounded by abnormal glucose levels during fasting and/or after a meal; additional therapy with insulin or other medications was required. Patients who presented both arterial hypertension and GDM were excluded from the study. Gestational hypertension was defined as a systolic blood pressure $>140 \mathrm{mmHg}$ or diastolic blood pressure $>90 \mathrm{mmHg}$ on two or more measurements at least six hours apart, occurring after 20 weeks of gestation, without concomitant proteinuria. Preeclampsia was defined as the onset of hypertension (systolic blood pressure $\geq 140 \mathrm{mmHg}$ or diastolic blood pressure $\geq 90 \mathrm{mmHg}$ ) in a previously normotensive woman, and proteinuria (at least $0.3 \mathrm{~g}$ of protein in a $24 \mathrm{~h}$ urine sample) without a concomitant urinary tract infection. Gestational diabetes was detected on the basis of a $75 \mathrm{~g}$ glucose tolerance test conducted between 24 and 28 weeks of gestation. All patients were in appropriate-for-gestational age (AGA) pregnancies. Fetuses were defined as AGA during pregnancy by an ultrasound scan. Patients, after in vitro fertilization, were excluded from the study, as were women with any other concomitant diseases. In all patients, serum $25(\mathrm{OH}) \mathrm{D}$ was determined during the hospital stay, up to seven days before delivery. Women presenting abnormal blood pressure were additionally examined for the severity of hypertension and presence of preeclampsia. Patient age, parity, body mass index (BMI), gestational age at delivery, route of delivery, birth weight and $\mathrm{pH}$ of the umbilical cord blood were analyzed. The control group included 36 women with uncomplicated pregnancies, normal arterial blood pressure and glucose concentrations. Baseline characteristics of study participants are presented in Table 5.

Table 5. Baseline characteristics of the study participants. NS: not significant; BMI: body mass index; P: $p$-value.

\begin{tabular}{cccc}
\hline Parameter & Study Group $\mathbf{N}=\mathbf{1 7 1}$ & Control Group $\mathbf{N = 3 6}$ & P \\
\hline Age (years) & $29.6 \pm 5.2$ & $29.4 \pm 4.9$ & NS \\
BMI $\left(\mathrm{kg} / \mathrm{m}^{2}\right)$ & $27.8 \pm 2.2$ & $26.9 \pm 2.4$ & NS \\
Parity & $1.9 \pm 1.1$ & $1.8 \pm 1.0$ & $\mathrm{NS}$ \\
$\mathrm{pH}$ of umbilical artery & $7.35 \pm 0.09$ & $7.35 \pm 0.07$ & $\mathrm{NS}$ \\
BMI $\left(\mathrm{kg} / \mathrm{m}^{2}\right)$ & $24.8 \pm 2.0$ & $25.2 \pm 2.5$ & $\mathrm{NS}$ \\
Pregnancy $\left(\mathrm{weeks}^{2}\right.$ & $38 \pm 2.96$ & $40 \pm 1.08$ & $\mathrm{NS}$ \\
Caesarian sections $\%$ & 43.3 & 37.6 & $\mathrm{NS}$ \\
Weight of newborn $(\mathrm{g})$ & $3340 \pm 680$ & $3590 \pm 430$ & $\mathrm{NS}$ \\
\hline
\end{tabular}

\subsection{Methods}

Blood samples of 10-mL were obtained from the cubital vein and immediately separated by centrifugation. The serum was stored at $-80{ }^{\circ} \mathrm{C}$ until analysis. Subsequently, serum $25(\mathrm{OH}) \mathrm{D}$ 
concentration was determined by ELISA (25-Hydroxy Vitamin D EIA), Immunodiagnostic Systems Ltd. in Department of Laboratory Diagnostics, Ludwik Rydygier Collegium Medicum, Nicolaus Copernicus University in Torun; sensitivity $2.0 \mathrm{ng} / \mathrm{mL}$ ( $5 \mathrm{nmol} / \mathrm{L})$, assay measured range was $2.7-152 \mathrm{ng} / \mathrm{mL}$ (6.8-380 nmol/L). A certified reference material (NIST Standard Reference Material (SRM) 972) was used for vitamin D measurement. The method remained under RIQAS control, and the results of the assay are within the reference range for this control. The inter- and intra assay variabilities were $5.3 \%$ and $4.6 \%$. Concentration of $25(\mathrm{OH}) \mathrm{D}<10 \mathrm{ng} / \mathrm{mL}(<25 \mathrm{nmol} / \mathrm{L})$ was defined as deficiency, $10-29 \mathrm{ng} / \mathrm{mL}$ (25-74 nmol/L) has been accepted as insufficiency, and sufficient when concentrations were between $30-100 \mathrm{ng} / \mathrm{mL}(75-250 \mathrm{nmol} / \mathrm{L})$.

\subsection{Statistical Analyses}

All statistical analyses were performed using the PQStat version 1.6 (StatSoft, Tulsa, OK, USA). The Mann-Whitney U-test and the Kruskal-Wallis test withpost-hoc Dunn's testwere applied to compareconcentrations of $25(\mathrm{OH}) \mathrm{D}(\mathrm{ng} / \mathrm{mL})$ between the groups. Relationships between serum concentrations of $25(\mathrm{OH}) \mathrm{D}(\mathrm{ng} / \mathrm{mL})$, patient age, $\mathrm{pH}$ of the umbilical cord blood and birth weight were assessed on the basis of Spearman's rank correlation coefficient values. Prediction of hypertension, preeclampsia and diabetes (GDM G1 and GDM G2) were analyzed with univariate and multivariate models of logistic regression. The influence of the concentration of the $25(\mathrm{OH}) \mathrm{D}$ on the appearance of hypertension and preeclampsia were also analyzed with ROC curves. $p$-Value $<0.05$ was considered statistically significant and $p$-value $<0.01$ was considered statistically highly significant.

The study design was approved by The Ethical Committee, of The LudwikRydygier Collegium Medicum in Bydgoszcz (decision No. KB 502/2013, 2 December 2013). All participants have provided the informed, written consent.

\section{Conclusions}

In conclusion, both the results of previous studies and our findings presented here, documenting the link between maternal deficiency of vitamin $\mathrm{D}$ and the increased risk of preeclampsia, point to the important role of an appropriate level and adequate metabolism of this vitamin in pregnancy. However, we are well aware of the potential limitations of this study. The relatively small size of the sample did not enable us to formulate any ultimate conclusions. Consequently, larger studies are needed to confirm the findings presented here and to explore their underlying etiopathogenic mechanisms. It would be necessary to get detailed information on vitamin D and calcium intake, as well as on patients' habits (outdoor activities and sunbathing). Available evidence is still insufficient to confirm a causative link between vitamin $\mathrm{D}$ and pregnancy disorders in line with Hill's criteria. Nevertheless, our study demonstrated a high prevalence of $25(\mathrm{OH}) \mathrm{D}$ deficiency/insufficiency among pregnant Polish women.

Author Contributions: Malgorzata Walentowicz-Sadlecka, Piotr Domaracki, Pawel Sadlecki conceived and designed the experiments; Piotr Domaracki, Malgorzata Walentowicz-Sadlecka, Grazyna Odrowaz-Sypniewska, Joanna Siodmiak performed the experiments; Pawel Walentowicz, Ewa Dzikowska, Malgorzata Walentowicz-Sadlecka; Marek Grabiec analyzed the data. Marek Grabiec contributed reagents/materials/analysis tools; Malgorzata Walentowicz-Sadlecka, Pawel Sadlecki, Piotr Domaracki wrote the paper.

Conflicts of Interest: The authors declare no conflict of interest.

\section{References}

1. Karras, S.; Paschou, S.A.; Kandaraki, E.; Anagnostis, P.; Annweiler, C.; Tarlatzis, B.C.; Hollis, B.W.; Grant, W.B.; Goulis, D.G. Hypovitaminosis D in pregnancy in the Mediterranean region: A systematic review. Eur. J. Clin. Nutr. 2016. [CrossRef] [PubMed]

2. Holick, M.F. Vitamin D and sunlight: Strategies for cancer prevention and other health benefits. Clin. J. Am. Soc. Nephrol. 2008, 3, 1548-1554. [CrossRef] [PubMed] 
3. Sutton, A.; MacDonald, P. Vitamin D: More than a "bone-a-fide" hormone. Mol. Endocrinol. 2003, 17, 777-791. [CrossRef] [PubMed]

4. Granado-Lorencio, F.; Olmedilla-Alonso, B.; Herrero-Barbudo, C.; Blanco-Navarro, I.; Blázquez-García, S.; Pérez-Sacristán, B. Simultaneous determination of vitamins A, E and 25-OH-vitamin D: Application in clinical assessments. Clin. Biochem. 2006, 39, 180-182. [CrossRef] [PubMed]

5. Fried, D.A.; Rhyu, J.; Odato, K.; Blunt, H.; Karagas, M.R.; Gilbert-Diamond, D. Maternal and cord blood vitamin D status and childhood infection and allergic disease: A systematic review. Nutr. Rev. 2016. [CrossRef] [PubMed]

6. Walentowicz-Sadlecka, M.; Grabiec, M.; Sadlecki, P.; Gotowska, M.; Walentowicz, P.; Krintus, M.; Mankowska-Cyl, A.; Sypniewska, G. 25(OH)D3 in patients with ovarian cancer and its correlation with survival. Clin. Biochem. 2012, 45, 1568-1572. [CrossRef] [PubMed]

7. Dusso, A.S. Kidney disease and vitamin D levels: 25-hydroxyvitamin D, 1,25-dihydroxyvitamin D, and VDR activation. Kidney Int. Suppl. 2011. [CrossRef] [PubMed]

8. Walicka, M.; Marcinowska-Suchowierska, E. Vitamin D deficiency during pregnancy and lactation. Ginekol. Pol. 2008, 79, 780-784. [PubMed]

9. Bener, A.; Al-Hamaq, A.O.; Saleh, N.M. Association between vitamin D insufficiency and adverse pregnancy outcome: Global comparisons. Int. J. Womens Health 2013, 5, 523-531. [CrossRef] [PubMed]

10. Rajagambeeram, R.; Abu Raghavan, S.; Ghosh, S.; Basu, S.; Ramasamy, R.; Murugaiyan, S.B. Diagnostic utility of heat stable alkaline phosphatase in hypertensive disorders of pregnancy. J. Clin. Diagn. Res. 2014. [CrossRef] [PubMed]

11. Gillon, T.E.R.; Pels, A.; von Dadelszen, P.; MacDonell, K.; Magee, L.A. Hypertensive disorders of pregnancy: A systematic review of international clinical practice guidelines. PLoS ONE 2014, 9, e113715. [CrossRef] [PubMed]

12. Khan, K.S.; Wojdyla, D.; Say, L.; Gülmezoglu, A.M.; van Look, P.F. WHO analysis of causes of maternal death: A systematic review. Lancet 2006, 367, 1066-1074. [CrossRef]

13. Bärebring, L.; Bullarbo, M.; Glantz, A.; LeuAgelii, M.; Jagner, Å.; Ellis, J.; Hulthén, L.; Schoenmakers, I.; Augustin, H. Preeclampsia and blood pressure trajectory during pregnancy in relation to vitamin D status. PLoS ONE 2016, 11, e0152198. [CrossRef] [PubMed]

14. Kazimierak, W.; Kowalska-Koprek, U.; Karowicz-Bilińska, A.; Berner-Trąbska, M.; Lenczowska-Wężyk, M.; Brzozowska, M.; Kuś, E. 24-hour Holter measurement of blood pressure in pregnant women and effectiveness of the treatment. Ginekol. Pol. 2008, 79, 174-176. [PubMed]

15. Szczepaniak-Chicheł, L.; Tykarski, A. Treatment of arterial hypertension in pregnancy in relation to current guidelines of the Polish Society of Arterial Hypertension from 2011. Ginekol. Pol. 2012, 83, 778-783. [PubMed]

16. Sibai, B.; Dekker, G.; Kupferminc, M. Pre-eclampsia. Lancet 2005, 365, 785-799. [CrossRef]

17. Głuchowska, M.; Kowalska-Koprek, U.; Karowicz-Bilińska, A. Evaluation of the usefulness of endoglin level as a predictor of preeclampsia in pregnant women with hypertension. Ginekol. Pol. 2013, 84, 835-840. [CrossRef] [PubMed]

18. Perez-Sepulveda, A.; Monteiro, L.J.; Dobierzewska, A.; España-Perrot, P.P.; Venegas-Araneda, P.; Guzmán-Rojas, A.M.; González, M.I.; Palominos-Rivera, M.; Irarrazabal, C.E.; Figueroa-Diesel, H.; et al. Placental aromatase is deficient in placental ischemia andpreeclampsia. PLoS ONE 2015, 10, e0139682. [CrossRef] [PubMed]

19. Kornacki, J.; Skrzypczak, J. Preeclampsia-Two manifestations of the same disease. Ginekol. Pol. 2008, 79, 432-437. [PubMed]

20. Weinert, L.S. International association of diabetes and pregnancy study groups recommendations on the diagnosis and classification of hyperglycemia in pregnancy: Comment to the international association of diabetes and pregnancy study groups consensus panel. Diabetes Care 2010, 33, e97. [CrossRef] [PubMed]

21. Wojcikowski, C.; Lech, M.; Chećka, Z.; Wierzchowska, J.; Lukaszuk, K. Large-scale screening for early diagnosis of gestational diabetes mellitus (GDM). Ginekol. Pol. 1997, 68, 297-301. [PubMed]

22. Genuis, S.J. Maternal and pediatric health outcomes in relation to gestational vitamin D sufficiency. Obst. Gynecol. Int. 2015, 2015, 501829. [CrossRef] [PubMed]

23. Pleskačová, A.; Bartáková, V.; Pácal, L.; Kuricová, K.; Bělobrádková, J.; Tomandl, J.; Kaňková, K. Vitamin $\mathrm{D}$ status in women with gestational diabetes mellitus during pregnancy and postpartum. BioMed Res. Int. 2015, 2015, 260624. [CrossRef] [PubMed] 
24. Kaur, H.; Sangha, R.; Cassidy-Bushrow, A.E.; Wegienka, G. Maternal-cord blood vitamin D correlations vary by maternal levels. J. Pregnancy 2016, 2016, 7474192.

25. Ali, M.M.; Vaidya, V. Vitamin D and cancer. J. Cancer Res. Ther. 2007, 3, 225-230. [CrossRef] [PubMed]

26. Dawodu, A.; Wagner, C.L. Prevention of vitamin D deficiency in mothers and infants worldwide-A paradigm shift. Paediatr. Int. Child Health 2012, 32, 3-13. [CrossRef] [PubMed]

27. Baggerly, C.A.; Cuomo, R.E.; French, C.B.; Garland, C.F.; Gorham, E.D.; Grant, W.B.; Heaney, R.P.; Holick, M.F.; Hollis, B.W.; McDonnell, S.L.; et al. Sunlight and vitamin D: Necessary for public health. J. Am. Coll. Nutr. 2015, 34, 359-365. [CrossRef] [PubMed]

28. Zhou, J.; Su, L.; Liu, M.; Liu, Y.; Cao, X.; Wang, Z.; Xiao, H. Associations between 25-hydroxyvitamin D levels and pregnancy outcomes: A prospective observational study in southern China. Eur. J. Clin. Nutr. 2014, 68, 925-930. [CrossRef] [PubMed]

29. Burris, H.H.; Rifas-Shiman, S.L.; Huh, S.Y.; Kleinman, K.; Litonjua, A.A.; Oken, E.; Rich-Edwards, J.W.; Camargo, C.A.; Gillman, M.W. Vitamin D status and hypertensive disorders in pregnancy. Ann. Epidemiol. 2014, 24, 399-403. [CrossRef] [PubMed]

30. Van Weert, B.; van den Berg, D.; Hrudey, E.J.; Oostvogels, A.J.; de Miranda, E.; Vrijkotte, T.G. Is first trimester vitamin D status in nulliparous women associated with pregnancy related hypertensive disorders? Midwifery 2016, 34, 117-122. [CrossRef] [PubMed]

31. Powe, C.E.; Seely, E.W.; Rana, S.; Bhan, I.; Ecker, J.; Karumanchi, S.A.; Thadhani, R. First trimester vitamin D, vitamin D binding protein and subsequent preeclampsia. Hypertension 2010, 56, 758-763. [CrossRef] [PubMed]

32. Hill, A.B. The environment and disease: Association or causation? Proc. R. Soc. Med. 1965, 58, $295-300$. [CrossRef] [PubMed]

33. Hyppönen, E. Vitamin D for the prevention of preeclampsia? A hypothesis. Nutr. Rev. 2005, 63, $225-232$. [CrossRef] [PubMed]

34. Villa, P.M.; Hämäläinen, E.; Mäki, A.; Räikkönen, K.; Pesonen, A.-K.; Taipale, P.; Kajantie, E.; Laivuori, H. Vasoactive agents for the prediction of early- and late-onset preeclampsia in a high-risk kohort. BMC Pregnancy Childbirth 2013, 13, 110. [CrossRef] [PubMed]

35. Lehnen, H.; Mosblech, N.; Reineke, T.; Puchooa, A.; Menke-Möllers, I.; Zechner, U.; Gembruch, U. Prenatal clinical assessment ofsFlt-1(soluble fms-like tyrosine kinase-1)/PIGF (placental growth factor) ratio as a diagnostic tool for preeclampsia, pregnancy-inducedhypertension and proteinuria. Geburtshilfe Frauenheilkd. 2013, 73, 440-445. [PubMed]

36. Holmes, V.A.; Young, I.S.; Patterson, C.C.; Maresh, M.J.; Pearson, D.W.; Walker, J.D.; McCance, D.R.; diabetesand preeclampsia intervention trial (dapit) study group. The role of angiogenic and antiangiogenic factors in the second trimester in the prediction of preeclampsia in pregnant women with type 1diabetes. Diabetes Care 2013, 36, 3671-3677. [CrossRef] [PubMed]

37. Zabul, P.; Wozniak, M.; Slominski, A.T.; Preis, K.; Gorska, M.; Korozan, M.; Wieruszewski, J.; Zmijewski, M.A.; Zabul, E.; Tuckey, R.; et al. A Proposed molecular mechanism of high-dose vitamin D3 supplementation in prevention and treatment of preeclampsia. Int. J. Mol. Sci. 2015, 16, 13043-13064. [CrossRef] [PubMed]

38. Mutter, W.P.; Karumanchi, S.A. Molecular mechanisms ofpreeclampsia. Microvasc. Res. 2008, 75, 1-8. [CrossRef] [PubMed]

39. Hyppönen, E.; Cavadino, A.; Williams, D.; Fraser, A.; Vereczkey, A.; Fraser, W.D.; Banhidy, F.; Lawlor, D.; Czeizel, A.E. Vitamin D and Pre-Eclampsia: Original data, systematic review and meta-analysis. Ann. Nutr. Metab. 2013, 63, 331-340. [CrossRef] [PubMed]

40. Haugen, M.; Brantsaeter, A.L.; Trogstad, L.; Aleksander, J.; Roth, C.; Magnus, P.; Meltzer, H.M. Vitamin D supplementation and reduced risk of preeclampsia in nulliparous women. Epidemiology 2009, 20, 720-726. [CrossRef] [PubMed]

41. Tabesh, M.; Salehi-Abargouei, A.; Tabesh, M.; Esmaillzadeh, A. Maternal vitamin D status and risk of pre-eclampsia: A systematic review and meta-analysis. J. Clin. Endocrinol. Metab. 2013, 98, 3165-3173. [CrossRef] [PubMed]

42. Pena, H.R.; de Lima, M.C.; Brandt, K.G.; de Antunes, M.M.; da Silva, G.A. Influence of preeclampsia and gestational obesity in maternal and newborn levels of vitamin D. BMC Pregnancy Childbirth 2015, 15, 112. [CrossRef] [PubMed] 
43. Mohaghegh, Z.; Abedi, P.; Dilgouni, T.; Namvar, F.; Ruzafza, S. The relation of preeclampsia and serum level of 25-hydroxyvitamin D in mothers and their neonates: A case control study in Iran. Horm. Metab. Res. 2015, 47, 284-288. [CrossRef] [PubMed]

44. Halhali, A.; Díaz, L.; Barrera, D.; Avila, E.; Larrea, F. Placental calcitriol synthesis and IGF-I levels in normal and preeclampticpregnancies. J. Steroid Biochem. Mol. Biol. 2014, 144, 44-49. [CrossRef] [PubMed]

45. Zehnder, D.; Evans, K.N.; Kilby, M.D.; Bulmer, J.N.; Innes, B.A.; Stewart, P.M.; Hewison, M. The ontogeny of 25-hydroxyvitamin D3 1 $\alpha$-hydroxylase expression in human placenta and deciduas. Am. J. Pathol. 2002, 161, 105-114. [CrossRef]

46. Farrant, H.J.; Krishnaveni, G.V.; Hill, J.C.; Boucher, B.J.; Fisher, D.J.; Noonan, K.; Osmond, C.; Veena, S.R.; Fall, C.H.D. Vitamin D insufficiency is common in Indian mothers but is not associated with gestational diabetes or variation in newborn size. Eur. J. Clin. Nutr. 2009, 63, 646-652. [CrossRef] [PubMed]

47. Loy, S.L.; Lek, N.; Yap, F.; Soh, S.E.; Padmapriya, N.; Tan, K.H.; Biswas, A.; Yeo, G.S.; Kwek, K.; Gluckman, P.D.; et al. Association of maternal vitamin D status with glucose tolerance and caesarean section in a Multi-Ethnic Asian Cohort: The growing up in Singapore towards healthy outcomes study. PLoS ONE 2015, 10, e0142239. [CrossRef] [PubMed]

48. Nobles, C.J.; Markenson, G.; Chasan-Taber, L. Early pregnancy vitamin D status and risk for adverse maternal and infant outcomes in a bi-ethnic cohort: The behaviors affecting baby and you (baby) study. Br. J. Nutr. 2015, 114, 2116-2128. [CrossRef] [PubMed]

49. Zhang, M.X.; Pan, G.T.; Guo, J.F.; Li, B.Y.; Qin, L.Q.; Zhang, Z.L. Vitamin D deficiency increases the risk of gestational diabetes mellitus: A meta-analysis of observational studies. Nutrients 2015, 7, 8366-8375. [CrossRef] [PubMed]

50. White, P. Pregnancy complicating diabetes. Am. J. Med. 1949, 7, 609-616. [CrossRef]

(C) 2016 by the authors; licensee MDPI, Basel, Switzerland. This article is an open access article distributed under the terms and conditions of the Creative Commons Attribution (CC-BY) license (http:/ / creativecommons.org/licenses/by/4.0/). 